\title{
PHILIP FRENEAU
}

Champion of Democracy 
THIS PAGE INTENTIONALLY LEFT BLANK 




\title{
PHILIP FRENEAU CHAMPION OF DEMOCRACY
}

\author{
By Jacob Axelrad
}

UNIVERSITY OF TEXAS PRESS, AUSTIN 
Title page portrait of Philip Freneau by courtesy of the New York Public Library

Library of Congress Catalog Card No. 66-15699

Copyright (C) 1967 Jacob Axelrad

All rights reserved

Printed by The University of Texas Printing Division, Austin

Bound by Universal Bookbindery, Inc., San Antonio

ISBN 978-0-292-72792-2 (library e-book)

ISBN 978-0-292-72836-3 (individual e-book) 
To

my wife

KATE 
THIS PAGE INTENTIONALLY LEFT BLANK 